\title{
Ethnic Identity Construction of Young Turkish Muslims in Britain*
}

\section{İngiltere'deki Müslüman Türk Gençlerinin Etnik Kimlik İnşası}

\section{Muhammed Babacan}

PhD Candidate, Teaching Assistant, University of Bristol, Department of Sociology Doktora Öğrencisi, Öğretim Asistanı, Bristol Üniversitesi, Sosyoloji Bölümü Bristol/UK mb15488@bristol.ac.uk| https://orcid.org/0000-0002-8845-4677

\section{Article Type / Makale Tipi}

Research Article / Araștırma Makalesi

DOI: $10.33420 /$ marife.1009354
Article Information / Makale Bilgisi

Received / Gelis Tarihi: 13.10.2021

Accepted / Kabul Tarihi: 24.12.2021

Published / Yayın Tarihi: 30.12.2021

Cite as / Atıf: Babacan, Muhammed. “İngiltere'deki Müslüman Türk Gençlerinin Etnik Kimlik İnşası". Marife 21/2 (2021): 727-747. https://doi.org/10.33420/marife.1009354

Plagiarism / Intihal: This article has been reviewed by at least two referees and scanned via a plagiarism software. / Bu makale, en az iki hakem tarafından incelendi ve intihal içermediği teyit edildi.

Copyright / Telif Hakkl: "This article is an open access article distributed under the terms and conditions of the Creative Commons Attribution-NonCommercial-NoDerivatives 4.0 (CC BY-NC-ND 4.0) International License." / "Bu makale Creative Commons Alıntı-GayriTicari-Türetilemez 4.0 (CC BY-NCND 4.0) Uluslar arası Lisansı altında lisanslanmıștır."

Ethical Statement / Etik Beyan: * This article is derived from my Master's dissertation titled "Ethnic Identity among Young Turkish-Speakers in Britain", which was approved by the University of Bristol, The School of Sociology, Politics, and International Studies in 2016. / Bu çalışma 2016 tarihinde Bristol Üniversitesi Sosyoloji, Siyaset Bilimi ve Uluslararası İlişkiler Fakültesi tarafından onaylanan "Ethnic Identity among Young Turkish-Speakers in Britain" konulu Yüksek Lisans tezim esas alınarak hazırlanmiștır.

e-ISSN : 2630-5550

www.marife.org 


\section{Ethnic Identity Construction of Young Turkish Muslims in Britain}

\section{Summary}

This paper examines how young Turkish Muslims in Britain construct their ethnic identity by looking at their relationships with their families, the Turkish community, the host society, and their religious attitudes and practices. The focus of this study is certainly young Turkish Muslims who have been relatively ignored in multicultural British society. By the youth, I refer to the generation who were born in or arrived in Britain at an early age, who live in two different cultural spaces, who are more open to social and cultural changes in their everyday lives - particularly through school, college, and other institutions - than their parents, and who thus construct their ethnic identities through two 'geopolitical dimensions': 'inside-out' and the 'outside-in'. This means that the identity process is built, not just in relation to individuals' relationships with their family, inside the community, and so on, but also in relation to outsiders' attitudes, treatments, and perceptions. What is important to grasp here is that there is a dynamic interaction from the inside-out and the outside-in. Britain allows one to better explore the effects of these two dimensions on the ethnic identity construction of young Turks. On the one hand, it is home to many social, cultural, political, and religious organisations which are promoted by Turkish communities to circulate and strengthen their identity. On the other hand, it also enables those young people to have relations with the wider society, especially the majority group. Thus, their identity negotiations are influenced both by internal and external forces.

A review of the literature demonstrates three primary deficiencies. Firstly, the past research conducted on the issue of young Turkish Muslims' ethnic identity in Britain is few and far between. Secondly, these studies have overlooked either the internal or external dynamics of that community which significantly influence ethnic identity construction in younger generations. Lastly, these studies, except one, are now over twenty years old. By focusing on the views, feelings, and experiences of young Turkish Muslims in Britain in relation to their families, the Turkish community, the host society, and their religious attitudes and practices, this paper aims to fill these gaps in the literature.

This article draws on semi-structured in-depth interviews with young Turkish Muslims who were born in or who arrived in Britain at an early age. Interviews were conducted in London and Bristol between 2016 and 2018 with 14 young Turks and, ranging in age from eighteen to thirty years. I also conducted unstructured interviews with 3 older Turkish people who gave information about the Turkish communities existing in Bristol. The interviews were sampled using the snowball technique, which served the purpose of accessing the participants and establishing trustworthy relations with them. To facilitate the coding of the transcripts, I used NVivo. I employed thematic analysis to identify and analyse patterns of meaning in the dataset.

The findings of the research show that the ethnic identity construction of young Turkish Muslims has taken place on a tension line that arises between their own culture and the dominant culture. Most of my young respondents are aware of their ethnic identities and the cultural, social, and religious values which are the building blocks of their identities. Their relationships with the family, Turkish community, friends, and the host society, and their religious attitudes and practices have positively influenced the construction and maintenance of their ethnic identities. In this respect, this study makes a significant contribution to the literature on the ethnic identity formation of young Turkish Muslims in Britain.

Keywords: Ethnic Identity, Religion, Britain, Turkish Community, Young Turkish Muslims.

\section{İngiltere'deki Müslüman Türk Gençlerin Etnik Kimlik İnșası}

Özet

Bu makale, İngiltere'deki Müslüman Türk gençlerinin aileleri, Türk toplumu, ev sahibi toplum ile olan ilişskilerinin ve dini tutum ve uygulamalarının etnik kimliklerine olan etkisini araştırır. Bu çalışmanın odak noktası çok kültürlü İngiliz toplumunda diğer azınlık gruplarına nazaran göz ardı edilen Müslüman Türk gençleridir. Gençlik ile kastettiğim İngiltere'de doğan veya İngiltere'ye erken yaşlarda gelen, iki farklı kültürel çevrede yaşayan, özellikle okul, kolej ve diğer kurumlar aracığılla günlük yaşamlarında ebeveynlerinden daha çok sosyal ve kültürel değişimlere açık olan ve etnik kimliklerini 'içten dışa' ve 'dıştan içe' olmak üzere iki 'jeopolitik boyut' aracllığıla inşa eden bireylerdir. Bu, kimlik sürecinin bireylerin yalnızca aileleriyle, kendi etnik gruplarıyla vb. olan ilişkileriyle değil, aynı zamanda dışarıdakilerin tutumları, davranışları ve algılarıyla ilgili olarak inşa edildiği anlamına gelir. Burada üzerinde durulması gereken husus, içeriden dışarıya ve dışarıdan içeriye dinamik bir etkileşimin olduğudur. İngiltere, bu iki boyutun genç Türklerin etnik kimlik inşası üzerindeki 
etkilerinin daha iyi araştırılmasına imkan sağlıyor. Ingiltere, bir yandan, Türk topluluklarının gençlerin kimliklerini sürdürmelerini ve güçlendirmelerini sağlamak amacıyla organize ettikleri çok sayıda sosyal, kültürel, siyasi ve dini kuruluşa ev sahipliği yaparken, öte yandan, bu gençlerin daha geniş toplumla, özellikle çoğunluk grubu ile ilişki kurmasını sağlar. Bu, kimlik müzakerelerinin hem iç hem de dış etkenlerden etkilendiğini göstermektedir.

Önceki çalışmalarla ilgili inceleme literatürde üç temel eksikliği ortaya çıkarmaktadır. İlk olarak, Ingiltere'deki Müslüman Türk gençlerinin etnik kimliğine dair geçmiş̧e yapılan araștırmalar çok azdır. Íkinci olarak, bu çalışmalar genç nesillerde etnik kimlik inşasını önemli ölçüde etkileyen o topluluğun iç veya dış dinamiklerini gözden kaçırmıştır. Son olarak, biri hariç bu çalışmaların üzerinden yaklaşı yirmi yıl geçmiş̧ir. Bu çalışma, İngiltere'deki Müslüman Türk gençlerinin aileleri, Türk toplumu, arkadaşları ve ev sahibi toplumla ilişsileri ve, dini tutum ve uygulamalarına dair görüss, duygu ve tecrübelerinden yararlanarak literatürdeki bu boşlukları doldurmayı amaçlamaktadır.

Bu makale, İngiltere'de doğan veya İngiltere'ye erken yaşta gelen Müslüman Türk gençleri ile yapılan yarı yapılandırılmış derinlemesine görüşmelere dayanmaktadır. 2016-2018 yılları arasında Londra ve Bristol'de yaşları on sekiz ile otuz arasında değișen 14 genç Türk ile görüşmeler yapılmıștır. Ayrıca Bristol'de yaşayan Türk toplulukları hakkında bilgi veren 3 yaşlı Türk ile yapılandırılmamıs görüșmeler yapılmıștır. Görüşmeler, katılımcılara ulașma ve onlarla güvenilir ilișkiler kurma amacına hizmet eden kartopu tekniği kullanılarak örneklenmiştir. Transkriptlerin kodlanmasın kolaylaştırmak için NVivo kullanılmıștır. Veri setindeki anlam kalıplarını belirlemek ve analiz etmek için tematik analiz kullanılmıştır.

Araștırmanın bulguları, Müslüman Türk gençlerinin etnik kimlik inşasının kendi kültürleri ile hakim kültür arasında oluşan bir gerilim hattına yerleştirildiğini göstermektedir. Gençlerin çoğu etnik kimliklerinin ve kimliklerinin yapı taşları olan kültürel, sosyal ve dini değerlerin farkındadırlar. Aileleri, Türk toplumu, arkadaşları ve ev sahibi toplumla ilişsileri, dini tutum ve uygulamaları etnik kimliklerinin inşasını ve sürdürülmesini olumlu olarak etkilemiştir. Bu açıdan bu çalış̧a, Ingiltere'deki Müslüman Türk gençlerinin etnik kimlik oluşumuna ilişkin literatüre özgün bir katkı sağlamaktadır.

Anahtar Kelimeler: Etnik Kimlik, Din, İngiltere, Türk Toplumu, Müslüman Türk Gençleri.

\section{Introduction}

Is ethnicity simply given, biologic, and referring to objective belief in common descent (Shils, 1957; Geertz, 1973)? Or is it subjective belief in common ancestry because of similarities of customs, physical type, and migratory memories (Weber, 1968)? Or is it dynamic, fluid, and changeable depending on circumstances and environment and thus constructed and reconstructed during social action and interaction (Barth, 1964; Maleševic', 2004; Jenkins, 2008)? In other words, as Banks (1996, cited in Jenkins, 2008, 47) properly emphasised, is ethnicity in actors' hearts (for primordialists) or their heads (for instrumentalists), or both? If it is always constructed, then in which ways do actors construct and negotiate their belief in ethnicity in everyday life? And specifically, to what extent do younger generations differ from their parents in terms of interaction with people and ideas, perceptions and feelings about being in between two cultures, yet more in a multicultural society? These are some of the key questions about ethnicity that will shed light on us in this study, in which we will examine how young Muslim Turks in Britain construct their ethnic identity.

The focus of this paper is certainly young Turkish Muslims who have been relatively ignored in multicultural British society. This is partly because research and policy have centred mainly on those groups that are much more "visible" in terms of being defined by their skin colour and that have been the more open victims of racism: Africans, African Caribbeans, Pakistanis, Indians, Bangladeshis, 
and Somalian (Enneli et al., 2005: 48). By the youth, I refer to the generation who were born in or arrived in Britain at an early age, who live in two different cultural spaces, who are more open to social and cultural changes in their everyday lives particularly through school, college, and other institutions - than their parents, and who thus construct their ethnic identities through two "geopolitical dimensions": "inside-out" and the "outside-in" (Modood, 2013, 127). This means that the identity process is built, not just in relation to individuals' relationships with their family, inside the community, and so on, but also in relation to outsiders' attitudes, treatments, and perceptions. What is important to grasp here is that there is a dynamic interaction from the inside-out and the outside-in. Britain allows one to better explore the effects of these two dimensions on the ethnic identity construction of young Turks. On the one hand, it is home to many social, cultural, political, and religious organisations which are promoted by Turkish communities to circulate and strengthen their identity. On the other hand, it also enables those young people to have relations with the wider society, especially the dominant group. Thus, their identity negotiations are influenced both by internal and external forces. How do young Muslim Turks in Britain then think of themselves? How do they define and construct their ethnic identities? What are the roles of their relations with the family, the Turkish community, and the host society on their ethnic identities? What roles do religious attitudes and practices have on their identity formation? I address in this paper to these questions.

A review of the literature reveals that only very few studies have focused on the ethnic identity formation of young Turkish people in Britain. Kucukcan's study (1999), The Politics of Ethnicity, Identity and Religion: Turkish Muslims in Britain, provides valuable information about the Turkish Muslim community in London. He mainly concentrates on the Turk-Islam ethnic identity. According to him, family relations and social organisations have a significant role in every stage of immigration and settlement. He asserts that traditional values are represented as an expression of Turkish identity and that religion is one of the most significant factors of Turkish identity formation. Yalcın's Ph.D. thesis (2000), Ethnic Identities in Action: The Experience of Turkish Young People in London, examines the relationships of young Turks in the family, community, and host society levels. It takes into consideration ethnic and sub-ethnic groups. His findings show that there are significant differences between how sub-ethnic groups affect their members in their relationships within the community and host society. Enneli's Ph.D. thesis (2001), Turkish-Speaking Young People in North London: A Case of Diversity and Disadvantage, focuses on the construction of young Turkish speaking-people's ethnic and religious identities and their attitudes towards family issues. She concluded that there are many differences among Turkish-speaking community members with relation to their ethnic and religious identities. Simsek's Ph.D. thesis (2012), Identity Formation of Cypriot Turkish, Kurdish and Turkish Young People in London in a Transnational Context, provides significant information regarding identity formation in young Turks in transnational social spaces. She found that young Turks do not see themselves as belonging to fixed categorisations and that their transnationalism has been shaped by their everyday life experiences which 
are, obviously, different from their parents.

The literature, however, demonstrates three primary deficiencies. Firstly, the past research conducted on the issue of young Muslim Turks' ethnic identity in Britain is few and far between. Secondly, these studies have overlooked either the internal or external dynamics of that community which significantly influence ethnic identity construction in younger generations. Lastly, these studies, except one, are now over twenty years old. Given that identity is always constructed depending on the social environment and interaction with others and changes in societies, it is important to explore how young Turkish Muslims in Britain construct their ethnic identities recently. This paper aims to fill these gaps in the literature. By drawing on the experience of young Turkish Muslims in London and Bristol, it examines how they construct their ethnic identity by taking into account their relationships with the family, the Turkish community, the host society, and religious attitudes and practices.

\section{The Context of Reception: Turkish People in Britain}

The Turkish diaspora makes up one of the largest immigrant communities in Western Europe. Although the vast majority live in Germany, there is a significant number settled in Britain too. The first migration movement from Turkey to Britain mainly began with the bilateral agreement struck between the two countries in 1970. However, the labour migration to Britain remained at extremely low levels compared to Germany, the Netherlands, and France. In contrast with these three countries, Britain became one of the centres of political immigration from Turkey that began in the 1970s and 1980s (Kucukcan, 1999, 6162). From 23 June 1989 to begin the visa application for the entry of Turkish citizens, Britain has launched a new policy. After the change of immigrant admission rules, visa and border control policies, immigration to Britain under the Ankara Agreement (also known as Turkish Businessperson Visa) has become the most common way.

It is hard to estimate the number of Turkish population in Britain as there is no consensus between the official data and the estimates of researchers. According to the Republic of Turkey Ministry of Foreign Affairs, its number is 400,000 (MFA, 2021). On the other hand, the only official data is based on the Census taken place in 2011. According to the Census, the total number of Turks $(101,721)$, Kurds $(48,977)$, and Cypriot Turks $(19,073)$ is 169,771 . Having said that, this number includes only write-in responses. The main reason for this controversial situation regarding the number of Turkish people is that these communities have not been included in the list of the ethnic groups recommended so far in Britain's censuses. The vast majority of the Turks in Britain live in London. The main reason for this is that many Turkish social networking, kinship, and patronage relations exist between the Turks who already moved there to make a community in that city (Kucukcan, 1999, 64-65). On the other hand, around 1500 Turkish people live in Bristol. According to the data which was obtained from 3 respondents who moved to Bristol around 20 years ago, the first migration to Bristol followed a similar pattern to migration to Britain in general. The main movement to Bristol started at 
the beginning of the 1990s. The first group mostly moved there from London, and, in the following years, their families and relatives then moved to Bristol. In 2006, they constituted a Turkish community in Bristol and opened a Turkish mosque.

\section{Conceptual Framework: Ethnicity and Ethnic Identity}

The core question is based primarily on how ethnicity is constructed by actors. Taking the idea of ethnicity at face value, it is referred, first and foremost, to blood ties. The view is that it is assumedly given at birth and then carried to the present by ways of shared myths, culture, and memories (Smith, 1986, 15). This primordial perspective of ethnicity is substantially discussed by Shils (1957) and Geertz (1973). By primordial attachment, Shils $(1957,142)$ refers to the ideas of innate blood ties, loyalty to an immediate group, certain ineffable importance, sacredness, and so on. His research on soldiers who fought in Second World War conclude that devoting themselves to their mission and their good performance in the war was rooted in their attachments or loyalties to their commanders, teammates, and families rather than their commitment to their patriotism and the symbols of political parties (Thompson, 1989, 47). Drawing this conclusion may be true in this exclusive time, but it cannot be applied to all conditions and ethnic groups. As anti-foundationalists argue, the concept of ethnicity is not universal and there are no universal criteria that is approved to explain ethnic relations (Maleševic', 2004, 145). The main problem here, indeed, revolves around its psychological reductionism. Shils' explanation of behaviours and feelings of soldiers on the battlefield is conditional and may not be valid in another situation. For that reason, it entails a risk to generalise the issue of ethnicity from a particular situation, ignoring the idea that ethnicity is a phenomenon constructed by the ways of various social, cultural, economic, territorial, and religious circumstances.

In some cases, ethnicity is determined, not by external and circumstantial forces, but by internalised attachments. This understanding of ethnicity views the concept as a collectivity of people cohabited and acted together. This idea is properly captured by Weber's argument that primarily sees ethnic membership as a political community that inspires the belief in common ancestry because of similarities of customs, physical type, and migratory memories (Weber, 1978, 389). But more importantly, this is a subjective belief in common ancestry rather than the reality of common ancestry. Jenkins $(2004,10)$ argues that Weber seems to be suggesting that collective political movement is to impact the belief in common descent insomuch that individuals see themselves as coming from a common background. Yet, further having common cultural traits such as language, religion, kinship, lifestyle, and so on, may contribute to ethnic closure, saying this in Weber's term "monopolistic social closure." (Maleševic', 2004, 130). The essential precondition for one group is based on mutual comprehensibility of the behaviour of others. For this reason, an ethnic group that draws boundaries with other social groups may be conceived as a distinct form of a status group (Jenkins, $2004,11)$. One reason of strong primordial ties emerging in some circumstances among the group actors is properly captured by Barth $(1969,15)$ who asserts that 
"if a group maintains its identity when members interact with others, this entails criteria for determining membership and ways of signaling membership and exclusion."

Furthermore, the social constructionist approach conceives ethnic identification as situationally variable and negotiable (Jenkins, 2004, 51). Ethnicity is a thing that is given different meanings as a social identity in situational ways. While, under some circumstances, individuals are seriously attached to their cultural and descent identities, in other conditions, these identities may be deemed trivial or worthless (Fenton, 2010, 6). In Rattansi's view (1999, cited in Maleševic' 2004, 146), ethnic identities are primarily "decentred, fragmented by contradictory discourses and by the pull of other identities." Experiencing discrimination and exclusion, for instance, can trigger individuals to self-identify in ethnic terms. It is argued that the process of forging a kind of reactive ethnicity becomes more salient once ethnic minority groups experience a perceived threat, hostility, and exclusion in such a way that these negative attitudes and perceptions sharpen ethnic-racial identity boundaries (Portes and Rumbaut, 2001, 284; Rumbaut, 2005, 129). Studies show that some disadvantaged Turkish immigrant youth in Germany (Çelik, 2017; Witte, 2018) and in the Netherlands (de Jong and Duyvendak, 2021) developed specific "destigmatisation strategies" (Lamont and Mizrachi, 2012; Lamont et al., 2016) through engaging in ethnic boundary work (Lamont and Mizrachi, 2012; Wimmer, 2008) to respond to various discrimination and prejudices. Çelik's study $(2017,9)$ illustrates that some young Turks in Germany were actively engaged in transforming ethnic boundaries in the discursive field and often stigmatised the dominant group in reverse, by associating negative ethnic stereotypes in their accounts with German identity and associating positive values with Turkish identity.

The situation of the Turkish minority group, in this context, has a contextual and complex aspect. In social science discourse, it is therefore spoken of "shifting identity" or "contextual ethnicity." (Baumann, 1999, 21). But the contextuality is also associated with the effect of modernisation on ethnicity (Bauman, 1996, Durkheim, 1997). According to Parson (1975, cited in Maleševic', 2004, 48), the process of modernization has transformed the character of ethnic groups that experience a process of de-socialization. From this point of view, one could argue that modernization has declined the idea of primordial sentiments among actors. Making a distinction between modernism and post-modernism, Bauman (1996, 18) argues that the former's problem of identity focused on the construction and maintenance of a solid identity, but the latter's problem of identity is mainly concentrate on the avoidance of fixation and keeping the options open. This also means that ethnicity is an individual identification as well as collective identification and modernization likely provides the people cosmopolitan ideas and makes them more individualistic.

\section{Data and Method}

This article draws on semi-structured in-depth interviews with young Turkish Muslims who were born or arrived in Britain at an early age. Interviews 
were conducted in London and Bristol between 2016 and 2018 with 14 young Muslim Turks and, ranging in age from eighteen to thirty years. The interviews were sampled using the snowball technique, which served the purpose of accessing the participants and establishing trustworthy relations with them (Hammersley and Atkinson, 2007, 34).

The interviews primarily took place in the following three social settings of the participants: cafés, workplaces, and mosques. The informants were told to choose a meeting place where they could feel more comfortable in expressing their emotions and thoughts. In addition to this, the settings were chosen by taking into consideration their convenience to make high-quality interviews. The interviews were conducted in Turkish and English, sometimes a mixture of the two, and lasted between thirty and fifty minutes. While the interviews involved the use of predetermined questions, they were flexible and involved open-ended questions which enabled the respondents to dwell upon certain issues more than others. The semi-structured interview design allowed for changing the order and wording of the interview questions depending on the direction of the interviews and the participants' initial responses, as well as ask further questions where necessary (Doody and Nooran, 2013, 30). To facilitate the coding of the transcripts, I used NVivo. I employed thematic analysis to identify and analyse patterns of meaning in the dataset (Braun and Clarke, 2006, 10). It helped create "key themes, concepts and emergent categories" (Ritchie et al., 2003, 220) with which to classify, organise, and understand the phenomena under study (Joffe and Yardley, 2004, 58).

\section{Ethnic Self-Definition}

Self-definition is central to ethnicity, which includes expressions of a relational or communal identity as well as cultural practices. The questions, "How would you describe your ethnic identity?" and "How do young Turkish Muslims in Britain think of themselves?" are crucial to explore what the most important factor/s in their self-description is/are (Meer, 2014, 39-40). These questions feature a situational and contextual nature (Modood et al., 1997, 292). That means what individuals say or believe about themselves in terms of ethnic identity may change according to a range of situations. Table 1 indicates the background information of the respondents, as well as how they define their own ethnic identities. 
Table 1. Ethnic Self-Definition and Background Information of Young Turkish Muslims

\begin{tabular}{|c|c|c|c|c|c|c|c|}
\hline Respondent & Sex & Age & $\begin{array}{l}\text { Place of } \\
\text { Birth }\end{array}$ & $\begin{array}{c}\text { City of } \\
\text { Residence }\end{array}$ & $\begin{array}{l}\text { Period of } \\
\text { Stay in } \\
\text { Britain } \\
\text { (in years) } \\
\end{array}$ & $\begin{array}{l}\text { Ethnic-Self } \\
\text { Definition }\end{array}$ & Religion \\
\hline 1 & $\mathrm{M}$ & 18 & London & London & Since birth & Turkish & Islam \\
\hline 2 & $\mathrm{~F}$ & 18 & Turkey & London & 10 & $\begin{array}{l}\text { Turkish- } \\
\text { Kurdish }\end{array}$ & Islam \\
\hline 3 & $\mathrm{M}$ & 27 & London & London & Since birth & $\begin{array}{l}\text { Turkish- } \\
\text { Turkish } \\
\text { Cypriot }\end{array}$ & Islam \\
\hline 4 & $\mathrm{M}$ & 24 & London & London & Since birth & Turkish & Islam \\
\hline 5 & $F$ & 18 & London & London & Since birth & $\begin{array}{c}\text { Turkish- } \\
\text { Kurdish- } \\
\text { British }\end{array}$ & Islam \\
\hline 6 & M & 25 & Turkey & London & 17 & $\begin{array}{c}\text { Turkish- } \\
\text { British }\end{array}$ & Islam \\
\hline 7 & $\mathrm{~F}$ & 30 & London & London & Since birth & Turkish & Islam \\
\hline 8 & $\mathrm{~F}$ & 28 & London & London & Since birth & Turkish & Islam \\
\hline 9 & $\mathrm{~F}$ & 18 & London & Bristol & Since birth & $\begin{array}{c}\text { Turkish- } \\
\text { British }\end{array}$ & Islam \\
\hline 10 & $\mathrm{M}$ & 21 & Turkey & Bristol & 9 & Turkish & Islam \\
\hline 11 & $\mathrm{~F}$ & 25 & Turkey & Bristol & 10 & Turkish & Islam \\
\hline 12 & $\mathrm{M}$ & 20 & Turkey & Bristol & 10 & Turkish & Islam \\
\hline 13 & M & 22 & Turkey & Bristol & 19 & $\begin{array}{c}\text { Turkish- } \\
\text { British }\end{array}$ & Islam \\
\hline 14 & M & 25 & Turkey & Bristol & 10 & $\begin{array}{c}\text { Turkish- } \\
\text { British }\end{array}$ & Islam \\
\hline
\end{tabular}

The above table shows that most respondents identified themselves as Turkish. Some of those interviewees strongly highlighted their Turkishness. It was portrayed as an identity that they would never give up. One, for instance, stated, "I am [a] more conservative Turk. I would define myself as a Turk" (Bristol, Male: 20). Another respondent who had similarly been born in Britain explained that "I am [one] hundred percent Turkish. When my friends [asked] me 'where are you from?' I would say I am from Turkey even [if] they [did] not [ask] whether [I was] born in England or not. I would always say [that I was] Turkish" (London, Male: 24). This strong emphasis on Turkishness thus is more related to the primordial ties that are given at birth and then carried into the present throughshared history and culture (Smith, 1986, 15).

It could be said that their intense feelings towards Turkishness did not have anything to do with their place of birth. As can be seen from Table 1, their place of birth did not correlate with any common ethnic identity. For this reason, their answers (e.g. Turkish or Turkish-British) should be approached by considering their attachments to their respective cultures. The roles of family, culture, and religious organisations in Britain may have influenced the construction of their ethnic identities. This view is posited by one respondent. When I asked him whether there was any way in which he did not feel Turkish, he said: "No, you are surrounded by your family and community which makes you like you are Turkish and part of the nation also" (London, Male: 18). This view echoes Waters's 
argument that "ethnic identification involves both choice and constraint. Children learn both the basic facts of their family history and the cultural content and practices associated with their ethnicity in their household." $(1990,19)$. It can be argued that, during adolescence, many youths may become deeply involved in learning about their ethnicity. As Phinney et al. $(2001,496)$ point out, getting to the level where one can achieve an ethnic identity depends on "socialization experiences in the family, the ethnic community, and the larger setting."

Furthermore, some respondents adopted hyphenated identities. Their narratives suggest that young Turkish Muslims in London have different ideas, feelings, and perceptions about their ways of life, culture, and ethnic backgrounds that surround them and thus their social interaction with the British society. While some strongly hold onto their ethnic background in the multicultural society, others believe in the necessity of learning from both cultures. Because of this conflict, some experienced hyphenated identities "as a third space." One female respondent (London, Female: 18a), for instance, who was born in London, stated that she felt like she could identify with three ethnicities, including Turkish, Kurdish, and British. She noted, "I mainly feel Turkish and Kurdish because my dad is Kurdish, and my mom is Turkish...I feel quite isolated because we are living in Watford where there is not a lot of Turkish families around...There is no[thing] like socialisation. I also feel British because I was born and brought up here." Faas's study $(2009,180)$ similarly suggests that Turkish youth in Europe had no singular identity but "employed hybrid ethno-national, ethno-local and national-European identities as a result of their national location and, especially, schooling and social class positioning (rather than migration histories)." Living in two different cultural spaces led the young Turks to have different experiences. It was seen as a challenge in some cases. Unlike their parents, their lifestyle in the host country and their connection to the country of origin are different and they are "more likely to embrace complex diasporic identities." (Song, 2003, 118).

\section{Relationships with the Family and the Turkish Community}

The first social interaction that children have begins in their family unit. Therefore, the family plays an immeasurably significant role in transmitting traditional values to the younger generations. This section will analyse the relationships of young Turkish Muslims with their families in the Turkish communities of London and Bristol. In order to obtain a better understanding of these relationships, three main issues will be examined in this section: their relationships with: (i) family; (ii) marriage; and (iii) the Turkish community.

\subsection{Family Relationships}

Family relations have an important place in the identity formation of young Turkish Muslims since parents, siblings, and other family members are "the source of children's first experiences related to ethnicity" (Phinney and Rosenthal, 1992, 153). The vast majority of the interviewees stated that they have good relationships with their mothers. Frequently mentioned reasons for their having such close relationships with their mothers included their being "like a (best) 
friend" with their children, being "open-minded," and the talk between them being "highly enjoyable." One respondent (London, Female: 18b) said that "My mom is my best friend. I could talk to her about anything, and I can always express my feelings to her." Some of the respondents stated that they have the closest relations with their siblings. For instance, one respondent (Bristol, Male: 20) said: "I am very close to my brother. Even though he is older than me, we have a friendly type of relationship. He supports me a lot financially and in everyday situations." On the other hand, just two of the thirteen respondents noted that they have good relationships with their fathers. One of the possible reasons for this is because they are often separated from their fathers for very long periods. Some respondents held this view because, being brought up in Turkey, they experienced a lack of fatherly love. Others did not have close relationships with their fathers because their fathers have to work long hours in Turkish restaurants in Britain. One respondent (Bristol, Female: 25), for instance, said that "We grew up far away from our father; therefore, there is always a distance and seriousness between me and my father."

In order to better understand the family relationships of the respondents, their independence from their parents was also interrogated. Kucukcan $(1999,75)$ and Yalcin $(2000,85)$ found that the majority of their respondents thought that their parents exercised excessive control over them. My research, on the other hand, reveals different results from their findings. When asked whether their parents exercise control over them, the majority of the respondents believed that it was a kind of their protection rather than their parents' being intolerant or strict. They believed their "parents [simply] do not want something bad happens to their children" (Bristol, Female: 18). One female interviewee noted that "at first, I thought that their behaviour was too strict; however, I later realised that it was the right decision for me" (London, Female: 18b).

When it came to making girlfriends or boyfriends, some respondents linked the issue directly with the cultural and religious attitudes of their parents. When I asked whether they could make their own decision regarding whom they could make a boyfriend or girlfriend, the respondents noted that "we are a strict, religious family" (London, Male: 18), that they could not have any "boyfriends because of the religion" (London, Female: 18a), that "my parents did not want me to make friends with non-Muslims because of our religion and culture" (Bristol, Male: 21), that "my mom would want me to make friends with Turkish or Muslim backgrounds rather than British, Christian, or any other ethnic background" (Bristol, Male: 20). It could be said that some cultural and religious values seem to be the main features of many Turkish parents. Furthermore, these findings on parental attitudes show that both the male and female respondents were under parental control in relation to making relationships. This might be because Turkish parents do not want their children to be involved in dangerous acts, such as drugs, sex, and prostitution, and that that is the reason why they want to protect them.

\subsection{Marriage}

Marrying somebody from an ethnic group is a very important indicator that 
shows whether there are any issues associated with ethnic, cultural, and religious backgrounds. In traditional Turkish culture, parents play a decisive role in determining a spouse for their children. It is argued, however, that, as a result of immigration to different countries, new patterns of marriage have appeared in the Turkish community (Kucukcan, 1999, 98).

When asked whether their parents believed that they should marry a person from their own culture, all of the respondents noted that their parents wanted them to marry someone from their culture. It is also a fact that all of them, besides two, stated that they would prefer marrying a person from their communities. Earlier studies (Enneli, 2001; Enneli et al., 2005; Jones, 2008) provide almost the same picture. Some of my respondents would be willing to marry a Muslim person from another ethnic background, but none of them would marry a non-Muslim, even if they were in love with them. They believe that "ethnic groups are not a problem - it is more to do with religion" (Bristol, Male: 20) "because he would be a Christian and it would not be acceptable" (Bristol, Female: 18) "because you will be judged in terms of religion, whereas, in terms of culture, you cannot be judged" (London, Female: 18b). Some male respondents verbalised that even though their religious beliefs allow them to marry Muslims from different ethnic groups, they would not prefer it. One interviewee, for instance, noted that "[ethnicity] would not stop me from marrying someone but I simply would not want to marry someone who is not from my own culture" (Bristol, Male: 25). They believed that, if they were married to someone from outside their community, they would have an "unhappy life" (Bristol, Male: 22), there would be "communication barriers with my mom and the lady" (Bristol, Male: 25). One can see from the above quotations that young Turkish Muslims consider the expectations of their parents and want their prospective spouses to have healthy relationships, not only with them but with their parents as well. This view also can be observed in Turkey, where people say, "when someone is married, families are married as well."

\subsection{Relationships inside the Turkish Community}

According to Markstrom-Adams (1992, 174), "[i]dentity formation is not wholly an individualistic process; rather, the social environment exerts its forms of power and influence." Interactions between Turkish people through various organisations and close social relationships have had an important influence on the development of ethnic identity in the young Turkish generation. These types of relationships will be analysed in the following two sub-sections.

\subsubsection{Turkish Community Organisations}

It is argued that cultural, religious, and political organisations serve a crucial function in the formation and maintenance of young Turkish people's identity in Britain (Kucukcan, 1999; Yalcin, 2000; Enneli, 2001; Communities and Local Government, 2009; Simsek, 2012). In London, there are many social, cultural, political, and religious organisations which are promoted by Turkish communities, whereas in Bristol, there are only just two official organisations, including the 
Bristol Somuncu Baba Turkish Mosque and the Bristol Yunus Emre Turkish Supplementary School. As soon as the mosque in Bristol was founded, an Imam was appointed by the Turkish Directorate of Religious Affairs to lead prayers and to provide religious services to the Turkish children and adults living there. At the supplementary school, on the other hand, young people are taught the Turkish language, Turkish culture, and religious subjects.

When asked if they were attached, or were members, of any Turkish organisations, the great majority of the respondents said that they were more involved in religious activities. Enneli $(2001,38)$ noted that religion plays a central role in some Turkish people's lives and, therefore, might be expected to be more involved in religious activities, especially those organised by Turkish Mosques. This is true for my respondents as well. Turkish Mosques are seen as the most important of all of the aforementioned organisations. When asked why they are involved in Mosque activities, many pointed out its importance in terms of "gathering together" (Bristol, Male: 25), "socialising" (London, Male: 25), "learning the Qur'an" (London, Female: 18b), "having religious talks" (London, Female: 18a), "meeting on special days" (Bristol, Female: 25), and "learning the Turkish language and culture" (Bristol, Male: 21). It could be said that Turkish Mosques are not only considered to be places that provide religious services but also places where social, cultural, and educational programmes and activities are carried out. It thus contributes to the construction of Turkish-Islamic identity. The events held in the mosques are purposed to reawaken Islamic identity among the group and transfer religious and cultural values to the younger generation (Kucukcan, 2009, 98).

\subsubsection{Friendship}

The friendship patterns of the young generation indicate that, although almost all respondents have friends from other ethnic groups, including both Muslims and non-Muslims, their close friends were mostly from the Turkish community. The reasons why they tended to only have best friends from their ethnic groups are that they could be "trusted" (Bristol, Female: 18), that they "shared the same values" (Bristol, Male: 20), that they followed "the same religious beliefs" (London, Female: 18a), and are "easier to get along with" (London, Male: 25). One respondent (Bristol, Male: 25), for instance, said that "My best friend is Turkish. This is because he is just who I can share everything with and trust."

Due to these and other similar reasons, the majority of respondents stated that it is easier to make friends from the group that they belonged to rather than other ethnic groups. Earlier research also shows that the majority of young Turkish Muslims prefer having contact with their ethnic groups (Kucukcan, 1999; Yalcın, 2000; Enneli, 2001; Simsek, 2012). The idea is that those the young Turks feel close to are those who are socially, culturally, and emotionally close to them. In that sense, they sought mutual sympathy and affectivity in their understanding of social relations. 


\section{Relationships with the Host Society}

Interaction with the host society is one of the main issues that immigrants have. In their new social and cultural environment, the migrants might find themselves in a position of obtaining some cultural elements of the host community, such as speaking its language. It should be pointed out that basic linguistic knowledge is seen as essential to a successful integration (Niessen and Huddleston, 2009, 116). On the other hand, attitudes of young Turkish Muslims towards language and participating in the social, cultural, and political lives or organisations of the receiving country may demonstrate how the young generation constructs their ethnic identity, as well as how those young people integrate within their host society.

In order to obtain a better understanding of this, three main issues will be examined in this section: language, participation in British organisations, and friendship patterns.

\subsection{Language}

Waters $(1990,116)$ argues that "language is one of the first elements of the immigrant culture to disappear over the generations." An ethnic language embraces the history, culture, and customs of the community it belongs to. Therefore, not being able to communicate in the ethnic language seems to be directly correlated to one's losing one's ethnic identity (Portes and Rumbaut, 2001, 113). In order to communicate with one's host society, though, immigrants have to speak the language of the receiving country.

First, it must be noted that according to my observations during the interviews, all respondents - except for one female who was born in London were able to speak Turkish fluently. In that sense, it could be said that there is no connection between the interviewees' ability to speak Turkish and their place of birth. When two of the respondents who were born in Britain were asked which language they would want to use during the interview, they stated that they would be able to express their feelings and ideas better in Turkish. As a side note, some respondents switched to Turkish or English whenever they felt more comfortable with one of the two languages.

With regards to the everyday lives of the respondents, the great majority of them noted that they mostly speak Turkish at home and with their Turkish friends. When asked whether their parents required them to speak Turkish at home, 10 out of the 14 interviewees explained that no such requirement existed in their homes. One (Bristol, Male: 25) respondent, for instance, said that "my mom asks me to speak English actually (laughing)." One might suggest that the reason for asking their children to speak Turkish at home is due to their not having the ability to speak English with them. Some of the respondents also noted that, sometimes, they preferred to speak English with their siblings. This was mainly because, since they had been born in Britain, they were more comfortable with the English language, thereby making it easier for them to explain their feelings and thoughts using that language. As one (London, Male: 25) of the respondents mentioned, "my 
brother and sister were born here so they understand English better."

\subsection{Participation in British Organisations}

As mentioned earlier, regular participation in the organisations of the host country is one of the most important indicators of how young immigrants will construct their identity. In that sense, in order to understand what type of relationships young Turkish Muslims have with British organisations, some relevant questions were asked of the respondents.

When asked whether they were members of British organisations, the great majority of them stated that they did not. Yalcin (2000) reports similar findings with this research. The reasons given by some of them for not being members of British organisations were that "I do not want to attend those organisations because, when they organise meetings, they primarily serve alcohol" (London, Female: 18b). Another respondent (London, Male: 18), moreover, stated that "I mostly come to this Mosque so, whatever I do, I do with the Mosque community I mean, with people the same age as me." One might suggest that religious beliefs and values provide a paradigm that influences the attitudes of some young people towards whether they will join British organisations.

Two other respondents, on the other hand, said that they are active members of student clubs at their universities. One (Male, Bristol: 22), for instance, explained, that "there is a football club that I play for." The other (Male, London: 24) respondent similarly joined an athletic club at university, saying that "I play tennis with my British friends." is important to keep in mind that social settings and groups influence one's activities. According to Van Tubergen $(2007,748)$, "people who are strongly integrated into a social group are assumed to be more likely to comply with the norms of that group." In that sense, the research demonstrates that the young generation's social settings play a crucial role in whether they become a member of a British organisation or not.

\subsection{Friendship Patterns and Socialisation}

The vast majority of the respondents stated that they have a circle of friends consisting of various British groups including English and thus they did not find it difficult to make friends with the members of a larger society and other ethnic minorities. Having said that they had a negative tendency towards socialising with the members of the English ethnic group. For some, cultural differences, personal preferences, and perceived differences in behaviours were decisive in their socialisation patterns. One respondent (London, Male: 27), for instance, stated that "I have friends from other ethnic groups, but it is limited because they want to drink and go to pubs. It is not easy to socialise with them." Another respondent (Bristol, Female: 25) expressed that "My social relation with English friends is more limited. It is more limited because I do not drink, I do not go to pubs or night clubs. But other than that, we are together at school and at different events like football." It seems that religious and cultural values have influenced the friendship patterns of the younger Turkish generation. Drinking and eating practices are fundamental elements in marking social and cultural differences, boundaries, and 
contradictions (Silva et al., 2014, 466). Social places in Britain that maintain these cultures play a key role in facilitating social interaction (Gordon et al., 2012, 5). However, my respondents marked such social and cultural settings as rarely visited places since they go counter to their religious or cultural values. This, therefore, appeared to be a reason that restricts their socialisation with their nonMuslim friends.

Another issue affecting the socialisation pattern of the young Turks with the English society was the belief that the attitudes and behaviours of the English people in social relations conflict with the typical socialisation pattern of the Turkish society. The first generations made up the majority of those with this view, but there were also considerable second generations. My finding demonstrates that even though social and cultural contexts of the first generations changed, they still applied to the socio-cultural values that they were used to in Turkey in establishing social relations with the host society. Nevertheless, the secondgeneration Turks experienced different social and cultural values within the British context where they might see themselves as being influenced by two different kinds of cultures and ways of life. The study shows that the dual socialisation process of some second generations emergent of a conflict where the attitudes and behaviours derived from the host society were seen incompatible with the home and ethnic community-based values of the social relations.

Some first and second generations described the English people as distant and insincere in social relationships. This was viewed as one of the reasons why they did not want to socialise with them. One respondent, for instance, expressed that

I think they are not as sincere as we are. They are not as much connected to each other, their families, and their friends as we are. They live very selfishly, individually. This lifestyle does not fit us. We are more embracing. We are very tight with friendship. So that is why we do not want to be friends with them (London, Female: 30 ).

It seems that individual or social behaviour patterns play a key role in social interaction in a multicultural society. Socio-cultural differences and habits can be seen as an obstacle to socialising with different social groups. It is clear from the data that identity construction is not a one-way process, but rather the nature of the social interaction directs it.

Accordingly, these young Turks tended to highlight their identification with their ethnic group. The extant literature also shows a similar pattern. Kucukcan (1999), Yalcin (2000) and Simsek (2012)'s studies suggest that Turkish youths emphasised the importance of being with friends and people from the same background. The emotional attachment that makes people feel more comfortable, securer and solidarity as well as reducing the feeling of strangeness might be explained by a shared culture and shared institutions, "constructed primordiality", (Cornell and Hartmann, 1998, 85-90) that are the most important factors promoting group stability and the persistence of ethnic attachments (Jenkins, 2008, 126).

One of the most significant findings, however, is that none of the 
participants raised a perceived threat or exclusion as a determinant factor in their relationships with the White British. In other words, their emphasis on a positive association with Turkish identification was not because they believed that they were being treated negatively by their English peers and thus developed "reactive ethnic identifications" (Portes and Rumbaut, 2001; Rumbaut, 2005). No participant reported any such experience. Rather they asserted that they were accepted by them. When I asked one respondent (Bristol, Male: 20), for instance, whether he had experienced a negative perception from his White British friends because of his ethnic or religious background, he verbalised, "No, they show understanding. They know who I am. I tell them if I need to pray, so they know what I am doing and respect it. They know that I am doing it because of my religious belief." In that sense, the limited socialisation with the White British people was a result of a decision based on the religion or culture-based preferences of the respondents rather than a reason for social exclusion or discrimination. They did not feel alienated and further did not isolate themselves from the host society completely.

\section{Religious Attitudes and Practices of Young Turkish Muslims}

Religion tends to be a significant source in the lives of most young Turkish people. When asked whether they are religious, many replied that they did consider themselves to be religious. This does not, however, mean that, for other young people, religion is not important in their everyday lives. Rather, they believed that they are not very interested in religious practices and, therefore, did not describe themselves as being religious. The initial instruction that they receive about Islam is mostly provided by the family. It has been found that young people practicing their family's religion are strongly linked to their parents' religiousness. This point was stressed by one of the respondents (Bristol, Male: 20), who stated that "my family would be my primary source [for attaining Islam]." In Britain, this initiation is typically supplemented and supported by religious and cultural organisations, such as supplementary schools and mosques. All of the respondents noted that they attended religious classes through either Turkish supplementary schools or Turkish mosques. In this respect, as the research reveals, the respondents were provided a religious education for them to gain some knowledge about Islam.

Furthermore, when asked how important religion was in their lives, respondents stressed that it shaped most of their lives. These young people's accounts indicate that Islam is seen as a source of guidance for practicing the religion and for living one's life. One respondent (London, Male: 18) stated that religion dictates "[e]verything. Like what I choose to eat, what I choose to wear, where I choose to go, who I choose to speak to." Respondents mostly emphasised their associating religiosity with action. As Kucukcan $(1999,156)$ points out, the ritualistic dimension of religion refers to certain practices expected of its followers. In that sense, Muslims are required to perform some obligatory practices, such as daily prayers (5 times a day), fasting throughout the entire month of Ramadan, and attending Friday prayers in a mosque. From the data, it is clear that some tried to keep their daily prayers, with some of the others stating that they wanted to 
perform all of the required prayers. Furthermore, all of the male respondents noted their commitment to going to the mosque for Friday prayers. Most of the respondents, further, stated that they fast during Ramadan.

On the other hand, when asked whether they ever ate non-halal meat, some confessed that, although, when they were younger, especially in primary school, they ate non-halal meat, they currently make sure that all of the food that they consume is halal. When asked whether they drank alcohol, highly important data emerged. 4 of the young people noted that they had drunk alcohol but had quit, whereas another two respondents said that they consume it at times. One interviewee (Bristol, Female: 18), for instance, stated that "[i]t depends on the situation. For example, I drink at special parties with my friends but not too much." Even though the use of alcohol is strictly forbidden in Islamic practice, it is, nonetheless, very common - not to mention extremely visible - in Western society. In this respect, one might suggest that, since Islamic and Western principles differ from one another, conflicts transpire between young people from these different cultures often.

\section{Conclusion}

This study rests on interviews with young Turkish Muslims in both London and Bristol, to empirically document how they construct their ethnic identities by considering their relationships both inside and outside of their community. It has been explored that the ethnic identity construction has taken place on a tension line that arises from between their own culture and the dominant culture. Their relationships with the family, Turkish community, friends, and the host society, and their religious attitudes and practices have positively influenced the construction and maintenance of their ethnic identities. In this respect, this study makes a significant contribution to the literature on the ethnic identity formation of young Turkish Muslims in Britain.

I have documented that most of my young respondents are aware of their ethnic identities and the cultural, social, and religious values which are the building blocks of their identities. They maintain adherence to their parents' ethnic origin and tend to make friends in the groups that they belong to, preferring to make friends with those who share the same values and religious beliefs as themselves. Moreover, although earlier research has found that parental control is very common among Turkish families, this research has revealed that parental control is perceived as a kind of protection rather than as acts of intolerance or being strict. Therefore, these young people's views about issues regarding marriage and making friends are almost the same as that of their parents. Turkish mosques and Turkish supplementary schools are seen as the most important of these organisations. These two places are not only considered to be places in which educational or religious services are provided but are also known places in which social and cultural activities are carried out.

Their attitudes towards the language, their participation in organisations of the receiving country demonstrate that bilingual young people, on the one hand, integrate into British society while, on the other hand, try to protect their ethnic 
and cultural identities. The findings confirm that cultural and religious values have greatly affected the attitudes of young people towards British society. Their friendship patterns and socialisation with the English group suggest that cultural differences, personal preferences, and perceived differences in behaviours rather than social exclusion or discrimination were decisive in their social relationships with the English people. Drinking and eating practices and the attitudes and behaviours of the English people in social relations played an effective role in the negative attitudes of the young Turkish Muslims towards the English ethnic group and identity.

A final implication of this study is that religion is one of the most significant sources of many young Turks' ethnic identity. Islam was seen by the respondents as a source of guidance that provides clear rules, not only about how to practice the religion but also as a way of life. They are highly organised around religious organisations. Being involved in religious activities helped construct their ethnoreligious identities. Therefore, religion in the Turkish diaspora provides a more significant contribution to the identification process of the young Turkish Muslims themselves and their commitment to their groups.

Funding / Finansman: This research received no external funding. / Bu araştırma herhangi bir dış fon almamıştır.

Conflicts of Interest / Çıkar Çatışması: The author declare no conflict of interest. / Yazar, herhangi bir çıkar çatışması olmadığını beyan eder.

\section{References}

Barth, Fredrik. "Introduction". Ethnic Groups and Boundaries: The Social Organisation of Culture Difference. ed. Fredrik Barth. 9-38. London: George Allen \& Unwin, 1969.

Bauman, Zygmunt. "From Pilgrim to Tourist - or a Short History of Identity". Questions of Cultural Identity. eds. Stuart Hall and Paul du Gay. 18-36. SAGE Publications, 1996.

Baumann, Gerd. The Multicultural Riddle: Rethinking National, Ethnic, and Religious Identities. London: Routledge, 1999.

Braun, V. and Clarke, V. "Using thematic analysis in psychology". Qualitative Research in Psychology, $3 / 2$ (2006), 77-101.

Çelik, Çetin. "Having a German passport will not make me German: reactive ethnicity and oppositional identity among disadvantaged male Turkish second-generation youth in Germany". Ethnic and Racial Studies, 38/9 (2015), 1646-1662.

Çelik, Çetin. "Disadvantaged, but morally superior: ethnic boundary making strategies of second-generation male Turkish immigrant youth in Germany". Global Studies in Culture and Power, 25/6 (2017), 705-723.

Communities and Local Government. The Turkish and Turkish Cypriot Muslim Community in England: Understanding Muslim Ethnic Communities. Change Institute, 2009.

Cornell, Stephen and Hartmann, Douglas. Ethnicity and Race: Making Indetities in a Changing World. London: Pine Forge Press, 1998.

De Jong, J., and Duyvendak, J. W. "Claiming the right to belong: de-stigmatisation strategies among Turkish-Dutch Muslims". Identities, (2021), 1-21.

Doody, 0. and Noonan, M. "Preparing and conducting interviews to collect data". Nurse Researcher, 20/5 (2013), 28-32.

Durkheim, Emile. The Division of Labor in Society. New York: The Free Press, 1997.

Enneli, Pinar. Turkish-Speaking Young People in North London: A Case of Diversity and 
Disadvantage. University of Bristol. PhD Thesis, 2001.

Enneli, Pınar, Modood, Tariq, and Bradley, Harriet. Young Turks and Kurds: A set of 'invisible' disadvantaged groups. York: Joseph Rowntree Foundation, 2005.

Faas, Daniel. "Young Turks in England and Germany: an exploration of their identity formation and perceptions of Europe". Turks in Europe: Culture, Identity and Integration. eds. Talip Kucukcan and Veyis Gungor. 155-183. Turkevi Research Centre, 2009.

Fenton, Steve. Ethnicity: Key Concepts. $2^{\text {nd }}$ ed. Cambridge: Polity Press, 2010

Geertz, Clifford. The Interpretation of Cultures. New York: Basic Books, 1973.

Gordon, R., Heim, D., and MacAskill, S. "Rethinking drinking cultures: A review of drinking cultures and a reconstructed dimensional approach". Public health, 126/1 (2012), 311.

Hammersley, Martyn and Atkinson, Paul. Ethnography: principles in practice. $3^{\text {rd }}$ ed. London: Routledge, 2007.

Jenkins, Richard. Rethinking Ethnicity: Arguments and Explorations. $2^{\text {nd }}$ ed. Sage Publications, 2008.

Joffe, H., \& Yardley, L. "Content and Thematic Analysis". Research Methods for Clinical and Health Psychology. eds. David F. Marks \& Lucy Yardley. 56-68. London: SAGE Publications, 2004.

Jones, A. Elisabeth. Language, Culture and Identity: the achievement and aspirations of Turkish, Kurdish and Turkish Cypriot Girls in North London Secondary Schools. PhD Thesis. University of Reading, 2008.

Kucukcan, Talip. Politics of Ethnicity, Identity and Religion: Turkish Muslims in Britain. Aldershot: Ashgate, 1999.

Kucukcan, Talip. "Turks in Britain: Religion and Identity". Turks in Europe: Culture, Identity and Integration. ed. Talip Kucukcan and Veyis Gungor. 79-102. Turkevi Research Centre, 2009.

Lamont, M., and N. Mizrachi. "Ordinary People Doing Extraordinary Things: Responses to Stigmatization in Comparative Perspective." Ethnic and Racial Studies, 35/3 (2012), 365-381.

Leloup, Fabienne. "Migration, a complex phenomenon". International Journal of Anthropology 11/2-4 (1996), 101-115.

Maleševic', S. The Sociology of Ethnicity. London: SAGE Publications, 2004.

Markstrom-Adams, C. "A Consideration of Intervening Factors in Adolescent Identity Formation". Adolescence Identity Formation. eds. Gerald R. Adams, Thomas P. Gullotta and Raymond Monternayor. 173-192. USA: Sage Publications, 1992.

Meer, Nasar. Key Concepts: Race and Ethnicity. London: SAGE Publications, 2014.

Modood, Tariq. Multiculturalism: A Civic Idea. $2^{\text {nd }}$ ed. Cambridge: Polity Press, 2013.

Modood, Tariq, Richard Berthoud, Jane Lakey, James Nazroo, Patten Smith, Satnam Virdee, and Sharon Beishon. Ethnic minorities in Britain: diversity and disadvantage. No. 843. Policy Studies Institute, 1997.

Modood, Tariq and Khattab, Nabil. Explaining Ethnic Differences: Can Ethnic Minority Strategies Reduce the Effects of Ethnic Penalties? Sociology, 50/2 (2016), 231-246.

Niessen, Jan and Huddleston, Thomas. "Legal Frameworks for the Integration of ThirdCountry Nationals". Series: Immigration and Asylum Law and Policy in Europe. 18 (2009).

Parsons, Talcott. "Some theoretical considerations on the nature and trends of change of ethnicity". Ethnicity: Theory and Experience. eds. N. Glazer and D. P. Moynihan. 53-83. Cambridge: Harvard University Press, 1975.

Phinney, Jean S. and Rosenthal, D. A. "Ethnic Identity in Adolescence: Process, Context, and Outcome". Adolescent Identity Formation. eds. G. R. Adams, T. P. Gullotin and R. Montemayor. 145-172. Newbury Park: Sage Publications, 1992.

Phinney, Jean S. Horenczyk, G., Liebkind, K. and Vedder P. "Ethnic Identity, Immigration, and Well-Being: An Interactional Perspective". Journal of Social Issues. 57/3 (2001), 493- 
510.

Portes, A., and Rubén G. Rumbaut. Legacies: The Story of the Immigrant Second Generation. Berkeley: University of California Press, 2001.

Ritchie, J., Spencer, L., and O'Connor, W. "Carrying out Qualitative Analysis". Qualitative Research Practice. eds. Jane Ritchie \& Jane Lewis. 219-262. London: SAGE Publications, 2003.

Rumbaut, R. G. "Sites of Belonging: Acculturation, Discrimination, and Ethnic Identity among Children of Immigrants". Discovering Successful Pathways in Children's Development: Mixed methods in the Study of Childhood and Family Life. ed. Thomas S. Weiner. 111164. Chicago: University of Chicago Press, 2005.

Simsek, Dogus. Identity Formation of Cypriot Turkish, Kurdish and Turkish Young People in London in a Transnational Context. City, University of London. PhD Thesis, 2012.

Shils, E. "Primordial, Personal, Sacred and Civil Ties". British Journal of Sociology. 8 (1957), 130-145.

Silva, T. H., de Melo, P. O. V., Almeida, J. M., Musolesi, M., and Loureiro, A. A. "You are what you eat (and drink): Identifying cultural boundaries by analyzing food and drink habits in foursquare". Eighth International AAAI Conference on Weblogs and Social Media, 2014.

Smith, Anthony D. The Ethnic Origins of Nations. Oxford: Basic Blackwell, 1986.

Song, Miri. Choosing Ethnic Identity. Blackwell Publishing, 2003.

Thompson, R. Theories of Ethnicity: A Critical Appraisal. New York: Greenwood Press, 1989.

Van Tubergen, F. "Religious affiliation and participation among immigrants in a secular society: a study among immigrants in the Netherlands". Journal of Ethnic and Migration Studies. 33 (2007), 747-765.

Waters, Mary C. Ethnicity Options: Choosing Identities in America. Berkeley: University of California Press, 1990.

Weber, Max. Economy and Society: An Outline of Interpretive Sociology. 2nd ed. London: University of California Press. 1978.

Wimmer, A. "The Making and Unmaking of Ethnic Boundaries: A Multilevel Process Theory." American Journal of Sociology, 113/4 (2008), 970-1022.

Witte, N. "Responses to stigmatisation and boundary making: destigmatisation strategies of Turks in Germany". Journal of Ethnic and Migration Studies. 44/9 (2018), 1425-1443.

Yalcın, Cemal. Ethnic Identities in Action: The Experience of Turkish Young People in London. London: University of Surrey. PhD Thesis, 2000. 